\title{
Cost Control Methods for Efficient HVAC in Office Building
}

\author{
Ar. P. Kalaivani
}

Abstract: Achieving Energy Efficiency in Office Buildings plays a key role in reducing the Environmental Impact of Buildings to a larger extent. The Users in the workplace are often affected by the improper design of HVAC systems. In most of the office buildings the Indoor Environmental conditions were not designed, controlled and maintained which in turn increases the Energy cost of the buildings. Sustainable Design of HVAC Systems includes all the mechanical equipments that efficiently controls, monitors and supplies the Indoor Air. The objective of this paper is to (i) Do a comparative study and analyses the various building Envelope in office buildings for reducing the Energy Cost in designing HVAC systems in Office buildings using Ecotect Modelling.(ii) To compare the Energy cost of Water Cooled Screw Chillers and VRF Systems.

The above experimentation was held in ELCOT $S$ office building in salem. The findings of this paper revealed that usage of Porotherm wall construction along with VRF SYSTEMS in office buildings found to be effective in achieving sustainable HVAC design.

Keywords : Energy Efficient Building Envelope, HVAC, Water Chiller, VRF(Variable Refrigerant Flow)

\section{INTRODUCTION}

$\mathbf{H}$ eating, Ventilation and Air conditioning (HVAC) system is designed in office buildings to provide Thermal Comfort to Occupants. Most of the HVAC systems are designed without proper controlling methods and hence enhances the Energy Cost in buildings. The design of the built Environment offer the base for the calculation of heating and cooling loads involving the design of building envelop and to floor areas. In particular, the orientation of walls, Building materials, and type of glass-together with any shading materials-plays a crucial role to proper calculation of solar loads and day lighting effects. The two basic needs of the design are to provide continuous air flow and achieving thermal comfort in indoor spaces. The best HVAC system is flexible enough to allow for adding or rearranging of zones as use changes. The operating and maintenance costs of HVAC systems will greatly exceed the installation cost due to poor design and maintenance. The teamwork of the Client and the architect, the HVAC designer plays a major role on a long-term economic basis that takes into account the life-cycle cost. [1-10].

\section{STUDY AREA}

Salem has moderate-dry weather throughout except during the monsoon season. The selected office building for case

Revised Manuscript Received on December 09, 2019.

P. Kalaivani, Assistant Professor, Kalasalingam school of Architecture, Krishnankoil. study is ELCOT in Jagir Ammapalayam Village, Salem Taluk, Salem. [21] Electronics corporation of tamilnadu Itd. (ELCOT) is an Administrative office to promote electronic Industries in Tamilnadu. It plays a major role in promoting electronic industries by endorsing joint business enterprises; providing advertising and administrative support for these projects and providing tools and application support for small and medium sectors. [21]

TABLE I. PROJECT DETAILS [21]

\begin{tabular}{|l|l|}
\hline Client & $\begin{array}{l}\text { Electronics corporation of } \\
\text { Tamilnadu }\end{array}$ \\
\hline Location & Ammapalayam, salem \\
\hline Land area & 53.33 acres \\
\hline Type of building & Admin office \\
\hline Type of office & $\begin{array}{l}\text { Open office to be rented to private } \\
\text { office }\end{array}$ \\
\hline Number of floors & S+3 \\
\hline $\begin{array}{l}\text { No of office space } \\
\text { proposed }\end{array}$ & 16 nos of 2000 sft approx \\
\hline $\begin{array}{l}\text { Total area of } \\
\text { conditioned space }\end{array}$ & 50,000 sft \\
\hline $\begin{array}{l}\text { Total tonnage of air } 350 \text { TR approx } \\
\text { conditioning }\end{array}$ & $1,63,84,000$ \\
\hline $\begin{array}{l}\text { Total cost of air } \\
\text { conditioning }\end{array}$ & RS.51200.00 \\
\hline Total cost/TR &
\end{tabular}

\section{METHODOLOGY}

The research is carried out by analyzing the overall thermal coefficient value of Building Envelope which further has been subjected to energy requirement calculation. Using ECOTECT for Building simulation, the AC consumption for Base case is determined for various office spaces through case studies and the outcome are evaluated to find the efficient model. 


\section{Cost Control Methods for Efficient HVAC in Office Building}

\section{SITE PLAN}

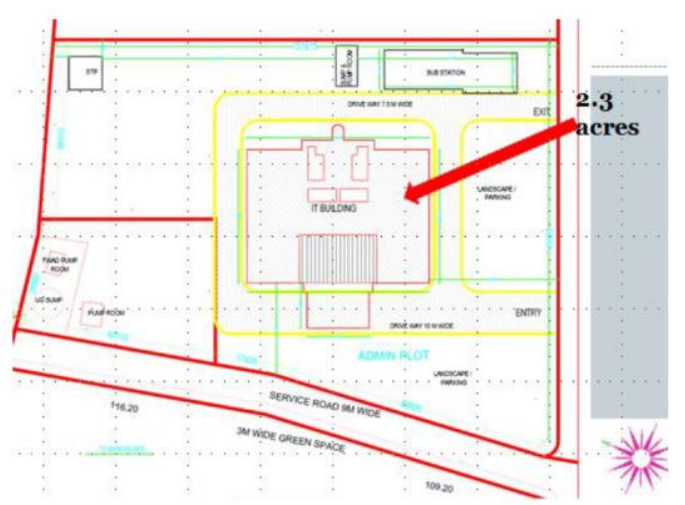

Fig 1.Site plan [21]

\section{RESULTS}

TABLE II. COMPARATIVE ANALYSIS OF WALLING MATERIAL

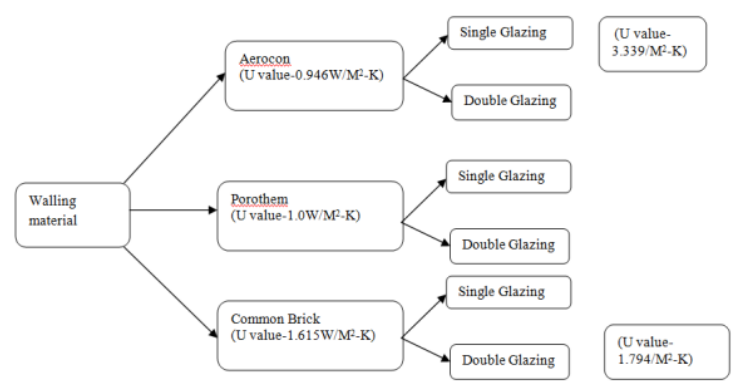

TABLE III. BASIS OF DESIGN

\begin{tabular}{|c|c|c|c|c|c|c|c|c|}
\hline \multicolumn{9}{|c|}{ BASIS OF DESIGN ELCOT-SALEM } \\
\hline $\begin{array}{l}\text { S. } \\
\text { N } \\
\text { o. }\end{array}$ & Floor & Description & Area & $\begin{array}{c}\text { No } \\
\text { of } \\
\text { Peop } \\
\text { le }\end{array}$ & $\begin{array}{c}\text { Light } \\
\text { s } \\
\text { (Watt } \\
\text { s/Sq.f } \\
\text { ) } \\
\end{array}$ & $\begin{array}{l}\text { Equip } \\
\text { (Watts) }\end{array}$ & $\begin{array}{c}\text { Total } \\
\text { IDU TR }\end{array}$ & $\begin{array}{c}\text { ODU } \\
\text { Capacity in } \\
\text { HP }\end{array}$ \\
\hline 1 & \multirow{8}{*}{$\begin{array}{l}\text { First } \\
\text { floor }\end{array}$} & OFFICE SPACE 1 & 2800 & 70 & 1.5 & 4000 & 18 & $21 \mathrm{HP}$ \\
\hline 2 & & OFFICE SPACE 2 & 3290 & 70 & 1.5 & 4000 & \multirow{2}{*}{22} & \multirow{2}{*}{$26 \mathrm{HP}$} \\
\hline & & & & & & 4000 & & \\
\hline 3 & & OFFICE SPACE 3 & 2860 & 70 & 1.5 & 4000 & 18 & $21 \mathrm{HP}$ \\
\hline 4 & & OFFICE SPACE 4 & 2860 & 70 & 1.5 & 4000 & 18 & $21 \mathrm{HP}$ \\
\hline \multirow[t]{2}{*}{5} & & OFFICE SPACE 5 & 3290 & 70 & 1.5 & 4000 & \multirow{2}{*}{22} & \multirow{2}{*}{$26 \mathrm{HP}$} \\
\hline & & & & & & 4000 & & \\
\hline 6 & & OFFICE SPACE 6 & 2800 & 70 & 1.5 & 4000 & 18 & $21 \mathrm{HP}$ \\
\hline 7 & \multirow{8}{*}{$\begin{array}{l}\text { Second } \\
\text { floor }\end{array}$} & OFFICE SPACE 1 & 2325 & 70 & 1.5 & 4000 & 18 & $21 \mathrm{HP}$ \\
\hline 8 & & OFFICE SPACE 2 & 3290 & 70 & 1.5 & 4000 & \multirow{2}{*}{22} & \multirow{2}{*}{$26 \mathrm{HP}$} \\
\hline & & & & & & 4000 & & \\
\hline 9 & & OFFICE SPACE 3 & 2860 & 70 & 1.5 & 4000 & 18 & $21 \mathrm{HP}$ \\
\hline 10 & & OFFICE SPACE 4 & 2540 & 70 & 1.5 & 4000 & 18 & $21 \mathrm{HP}$ \\
\hline 11 & & OFFICE SPACE 5 & 2970 & 70 & 1.5 & 4000 & \multirow{2}{*}{22} & \multirow{2}{*}{$26 \mathrm{HP}$} \\
\hline & & & & & & 4000 & & \\
\hline 12 & & OFFICE SPACE 6 & 2090 & 70 & 1.5 & 4000 & 18 & $21 \mathrm{HP}$ \\
\hline 13 & \multirow{8}{*}{$\begin{array}{c}\text { Third } \\
\text { floor } \\
\text { (ROOF- } \\
\text { INSULA } \\
\text { TED) }\end{array}$} & OFFICE SPACE 1 & 2800 & 70 & 1.5 & 4000 & 18 & $21 \mathrm{HP}$ \\
\hline 14 & & OFFICE SPACE 2 & 3290 & 70 & 1.5 & 4000 & \multirow{2}{*}{22} & \multirow{2}{*}{$26 \mathrm{HP}$} \\
\hline & & & & & & 4000 & & \\
\hline 15 & & OFFICE SPACE 3 & 2860 & 70 & 1.5 & 4000 & 18 & $21 \mathrm{HP}$ \\
\hline 16 & & OFFICE SPACE 4 & 2860 & 70 & 1.5 & 4000 & 18 & $21 \mathrm{HP}$ \\
\hline 17 & & OFFICE SPACE 5 & 3290 & 70 & 1.5 & 4000 & \multirow{2}{*}{22} & \multirow{2}{*}{$26 \mathrm{HP}$} \\
\hline & & & & & & 4000 & & \\
\hline \multirow[t]{3}{*}{18} & & OFFICE SPACE 6 & 2800 & 70 & 1.5 & 4000 & 18 & $21 \mathrm{HP}$ \\
\hline & & & & & & & & \\
\hline & & & & & & & 348 & $408 \mathrm{HP}$ \\
\hline
\end{tabular}

The paper is carried out initially by comparing Packaged A/C systems and VRF systems in which after analysis VRF systems are considered beneficial. Also the site and case study considerations to triangulate the beneficiary nature of VRF and to find the economic and efficient measure to be undertaken in an office building. The considerations included the size of the site, location, height of the building, floor to floor heights and the building materials used. Excepting the building materials, all the other factors have been kept constant for analysis.

TABLE IV. ENERGY COMPARISON BETWEEN VRF System Vs PACKAgEd AIR CONDITIONING SySTEMS

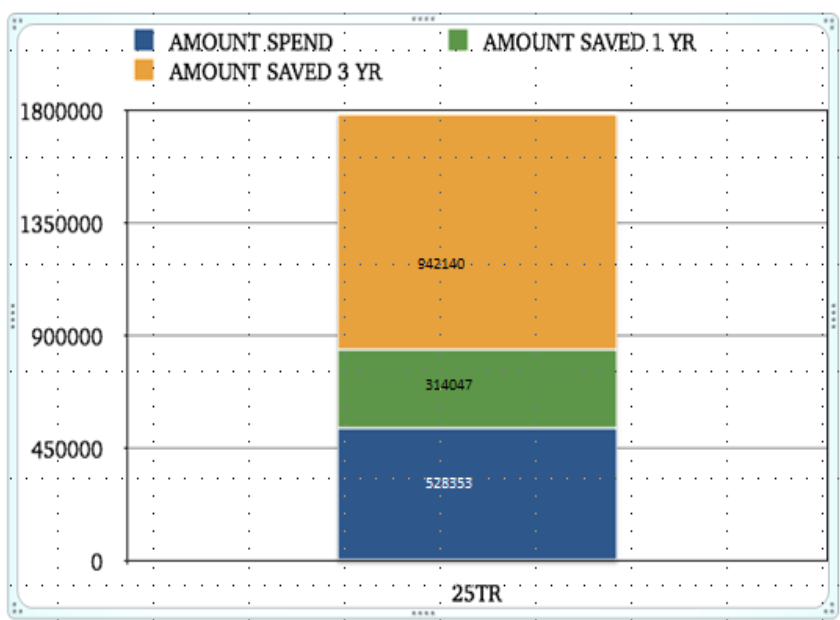

TABLE V. VRF SYSTEM

\begin{tabular}{|c|c|c|c|c|c|}
\hline & DVRF SYSTEM ELCOT-S & SALE & & & \\
\hline & PRICES FOR SUPPLY OF VRF & EQU & PME & & \\
\hline $\begin{array}{l}\text { SL } \\
\mathrm{N} \\
\mathrm{O}\end{array}$ & DESCRIPTION & UN & $\underset{Y}{Q T}$ & $\begin{array}{c}\text { RATE, } \\
\text { Rs }\end{array}$ & AMOUNT, \\
\hline 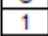 & Outdoor units & & & & \\
\hline & $\begin{array}{l}\text { Supply and installation of Variable } \\
\text { Refrigerant Flow system (with R-410 A) } \\
\text { connectable to multiple indoor units. Outdoor } \\
\text { unit shall be factory assembled weather } \\
\text { proof casing constructed from heavy gauge } \\
\text { mild steel panels with epoxy coated painting. } \\
\text { VRF outdoor unit shall comprise of high } \\
\text { efficiency scroll compressors with } \\
\text { Digitallnverter compressors and at least } \\
\text { having } 1 \text { variable compressor and } 11 \text { or } 2 \\
\text { constant speed compressors. The aluminum } \\
\text { fins shall be covered with anti-corrosion } \\
\text { resin. The unit shall be completely factory } \\
\text { wired and tested with necessary controls. } \\
\text { The unit shall be compatible for BMS } \\
\text { operation. Oil swapping system is } \\
\text { recommended where ever one or two } \\
\text { outdoor unit modules are interconnected, } \\
\text { where the oil sis swapped to the next ODU on } \\
\text { a regular basis to maintain the oil balanne } \\
\text { between the system. System should } \\
\text { comprise of safely devices like HP/LP } \\
\text { control, anti freeze protection, over current } \\
\text { protection, discharge temperature control. }\end{array}$ & & & & \\
\hline & 21 HP VRF Outdoor Unit (21 HP) & \begin{tabular}{|l|} 
No \\
5
\end{tabular} & 14 & $\begin{array}{r}4590 \\
0 \\
\end{array}$ & $4,842,800$ \\
\hline & 26 HP VRF Outdoor Unit (14+12 HP) & \begin{tabular}{|l|} 
No \\
5
\end{tabular} & 8 & $\begin{array}{r}54845 \\
0\end{array}$ & $4.387,600$ \\
\hline 2 & Indoor units & & & & \\
\hline & Ductable unit & & & & \\
\hline & $\begin{array}{l}\text { Supply and installation of indoor Units shall } \\
\text { be ceiling mounted Ductable units as } \\
\text { specified. The indoor unit shall have } \\
\text { independent electronic control valve to } \\
\text { control the refrigerant flow rate respond to } \\
\text { variations of the air conditioning load of the } \\
\text { room. The indoor units shall be suitable for } \\
\text { operation on } 1 \text { phase AC power supply. }\end{array}$ & & & & \\
\hline a & $6 \mathrm{TR}$ & \begin{tabular}{|l|} 
No \\
5
\end{tabular} & 42 & 35400 & $1,486,800$ \\
\hline b & $8 \mathrm{TR}$ & \begin{tabular}{|l|}
$\begin{array}{l}\text { No } \\
\text { s }\end{array}$ \\
\end{tabular} & 12 & 35400 & 424,800 \\
\hline 3 & Corded & No & 54 & 2400 & \\
\hline
\end{tabular}




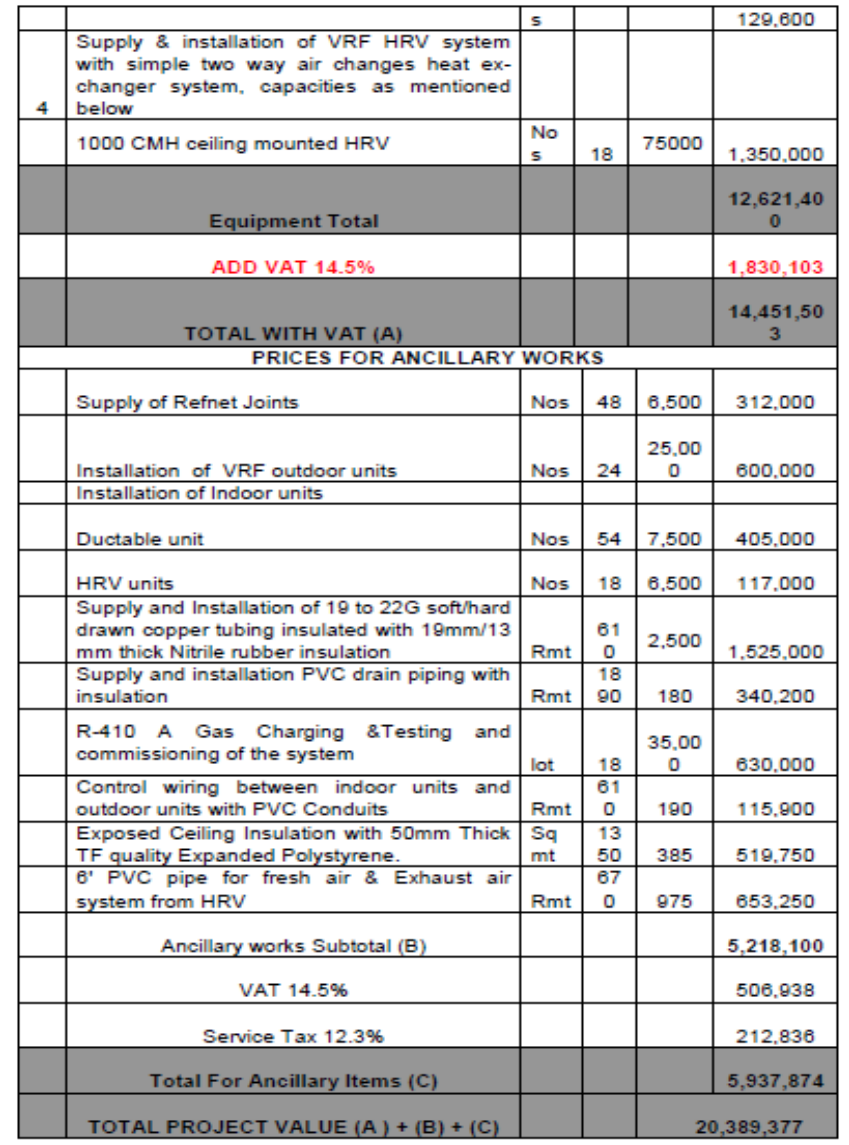

- The specifications were considered for Aerocon, porotherm and Common Brick with Single and double glazing.

- The Result shows that the Tonnage required for all three walling material with single glazing is higher when compared to the double glazing.

- Therefore single glazing is being ruled out.

- Now considering the double glazing parameters, Aerocon and porotherm has lower tonnage value.

TABLE VI. EXPECTED OUTCOME

\begin{tabular}{|c|c|c|c|}
\hline S.no & Description & & \\
\hline & & $\begin{array}{l}\text { Water cooled } \\
\text { chiller }\end{array}$ & Vrf system \\
\hline \multirow[t]{2}{*}{1} & $\begin{array}{c}\begin{array}{c}\text { Total conditioned area in } \\
\text { sqm }\end{array} \\
\end{array}$ & 4362 & 4662 \\
\hline & Total tr installed & 320 & 350 \\
\hline 2 & Cost of chiller & 5188800 & \\
\hline 3 & Cost of ahu & 9454800 & \\
\hline 4 & $\begin{array}{l}\text { Cost of hrv and misc } \\
\text { units }\end{array}$ & 1740400 & \\
\hline 5 & $\begin{array}{l}\text { Cost of vif system as per } \\
\text { quote }\end{array}$ & & 20389377 \\
\hline 7 & Total cost & 16384000 & 20389377 \\
\hline 8 & \begin{tabular}{|l|} 
Average cost / tr \\
\end{tabular} & 51200 & 58255 \\
\hline A & \multicolumn{3}{|c|}{$\begin{array}{l}\text { From this table we would find that and discuss that water cooled } \\
\text { system is the best economical system of air conditioning. But one } \\
\text { should also consider the indirect cost which is added in to the system. }\end{array}$} \\
\hline B & \multicolumn{3}{|c|}{$\begin{array}{l}\text { From the table it is also found that the total salable area is around } 300 \\
\text { sqm more than that of water cooled chiller }\end{array}$} \\
\hline 9 & Area of ahu & 360 & 60 \\
\hline 10 & Area of plant room & 220 & Nil \\
\hline 11 & $\begin{array}{l}\text { Cost of const @20000/ } \\
\text { sqm }\end{array}$ & & \\
\hline A & For ahu & $7,200,000.00$ & 1200000 \\
\hline \multirow[t]{2}{*}{ B } & For plant room & $4,400,000.00$ & 250000 \\
\hline & & & $\begin{array}{l}\text { (for slab } \\
\text { strenthening) }\end{array}$ \\
\hline \multirow[t]{2}{*}{12} & $\begin{array}{l}\text { Total cost of the over all } \\
\text { system }\end{array}$ & $27,984,000.00$ & 21839377 \\
\hline & & $12=11 a+11 b+7)$ & \\
\hline 13 & average cost / tr & $87,450.00$ & $62,398.22$ \\
\hline
\end{tabular}

TABLE VIII. COMPARISON BETWEEN BASE CASE AND PROPOSED ENERGY CONSUMPTION

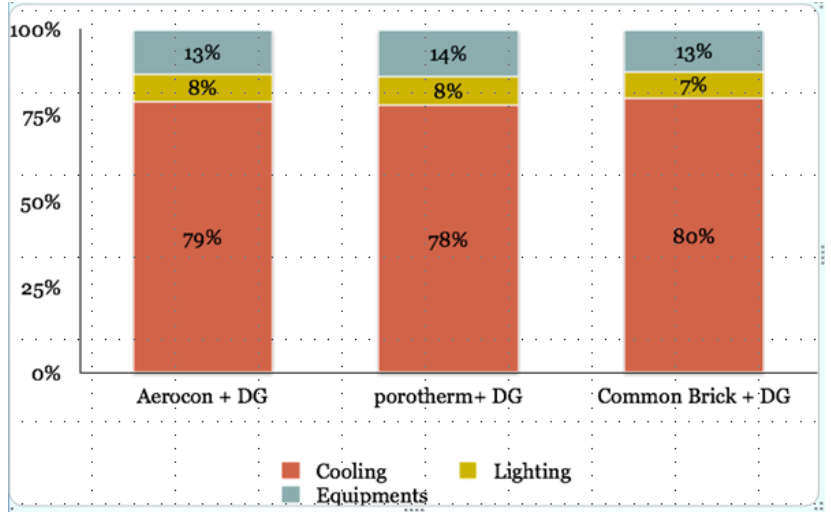

VRF System is the best economical system of air conditioning for office complex with multiple office spaces, or office complex which has lesser occupancy ratio at any point of time and suitable for both cubical type offices and open type office spaces.

TABLE IX. COMPARISON BETWEEN BASE CASE AND PROPOSED ENERGY CONSUMPTION IN KWH

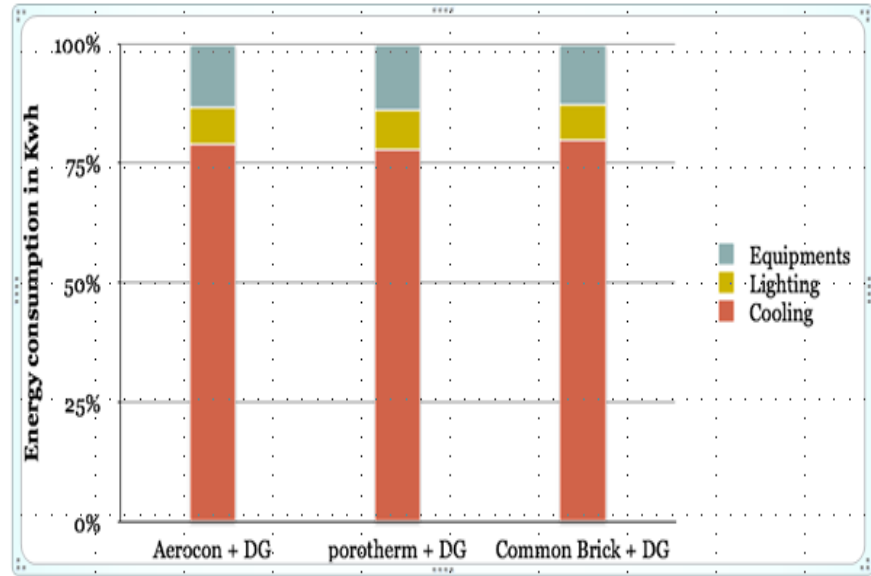




\section{Cost Control Methods for Efficient HVAC in Office Building}

\section{ANALYSIS}

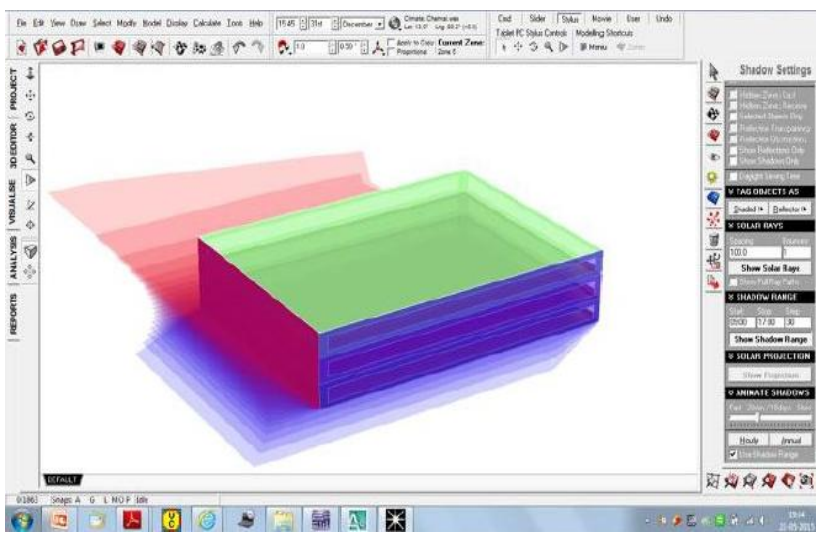

Fig 2. Thermal analysis of the building _ Building profile showing morning and noon shadow range - Heat gain based on building profile and orienttion (Favours high amount of heatgain)

CASE 1 - ANAlysis (Brick AND Single glazing GLASS) The case 1 building is a 3 storied structure with 3.75 floor to floor heights covering a total area of 6000sq.m approximately. The material used are brick and glass which is $200 \mathrm{~mm}$ thick upto $0.75 \mathrm{~m}$ plastered with cement and glazing $2.1 \mathrm{~m}$ (single glazing with aluminium frames) respectively.

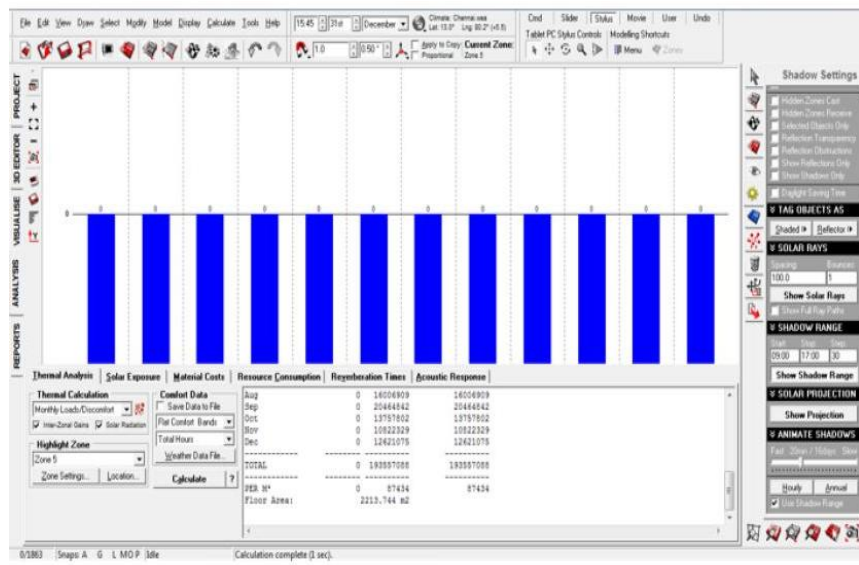

Fig 3. Thermal analysis of Case 1 _ Brick \& glass as building materials Total cooling load required per year of operation - 1, 93, $557 \mathrm{KW} / \mathrm{hr}$

\section{CASE 2 - ANALYSIS (PoRotherM BLOCK AND DOUBLE} GLAZING GLASS)

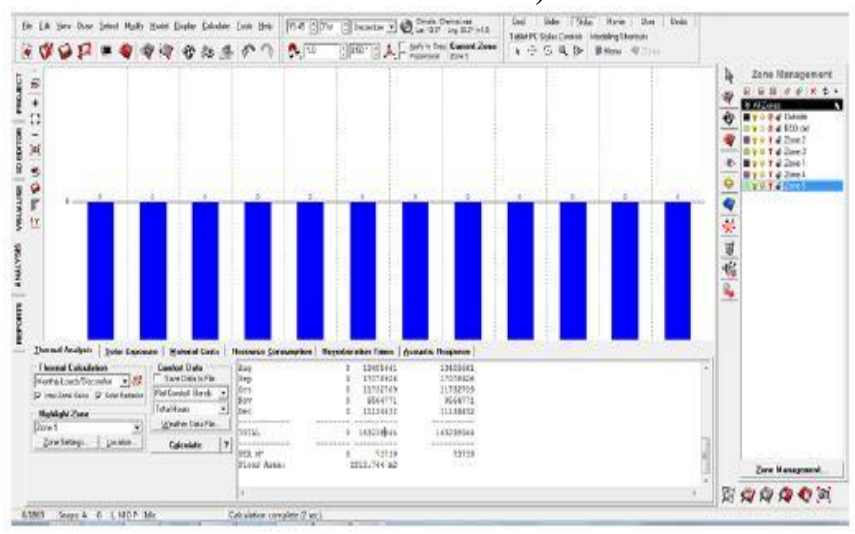

Fig 4. Thermal analysis of Case 1 _ Porotherm block \& double glazing glass as building materials
MOIITHLY HEATING/COOLIIIG LOADS

Zone: Zone 5

Operation: Weekdays 12-12, Weekends 00-24.

Thermostat Settings: $27.0-27.0 \mathrm{C}$

Max Heating: $0.0 \mathrm{C}$ - No Heating.

Max Cooling: $193759 \mathrm{~W}$ at 12:00 on 12th May

\begin{tabular}{|c|c|c|c|}
\hline MOIITH & $\begin{array}{l}\text { HEATING } \\
\text { (Wh) }\end{array}$ & $\begin{array}{c}\text { COOLIIIG } \\
\text { CWh })\end{array}$ & $\begin{array}{l}\text { TOTAL } \\
\text { (Wh) }\end{array}$ \\
\hline$\ldots . .$. & .... & ........... & ..... \\
\hline Jan & 0 & 9524912 & 9524912 \\
\hline Fob & 0 & 11390839 & 11390839 \\
\hline Mar & 0 & 16683312 & 16683312 \\
\hline Apr & 0 & 20813564 & 20813564 \\
\hline May & 0 & 19535128 & 19535128 \\
\hline Jun & 0 & 21830790 & 21830790 \\
\hline Jul & 0 & 20105564 & 20105564 \\
\hline Aug & 0 & 16006909 & 16006909 \\
\hline Sop & 0 & 20464842 & 20464842 \\
\hline Oct & 0 & 13757802 & 13757802 \\
\hline Hov & 0 & 10822329 & 10822329 \\
\hline Dec & 0 & 12621075 & 12621075 \\
\hline$\ldots . . .$. & $\cdots$ & ............. & n............. \\
\hline TOTAL & 0 & 193557088 & 193557088 \\
\hline 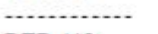 & $\cdots$ & ................ & ................... \\
\hline PER $M^{2}$ & 0 & 87434 & 87434 \\
\hline Floor Area: & 221 & $\mathrm{~m} 2$ & \\
\hline
\end{tabular}

The case 2 building is a 3 storied structure with 3.75 floor to floor heights covering a total area of 6000sq.m approximately. The material used are porotherm block and glass which is $200 \mathrm{~mm}$ thick up to $0.75 \mathrm{~m}$ plastered with cement and glazing $2.1 \mathrm{~m}$ (double glazing with low e-glass and aluminium frames).

\section{CONCLUSION}

This paper investigated enhancement in energy efficiency of an air conditioned building block employing energy management procedures like altering the use of envelope materials for walls, roof and window glazing and air conditioning system. The cooling system which is being used for this project is a new and emerging technology, VRF system which consumes more energy and is considered energy efficient when compared to the conventional chiller cooling system. And it is being proved by the previous results. The alternate material which is considered for the study, porotherm brick has by products with embodied energy taken as zero which will reduce the total life cycle energy demand dramatically by incorporating sustainable strategies in the design process itself. The Thermo Physical properties of various Building Materials and their U-Value will make them an ideal building envelope for wall construction.

\section{REFERENCES}

[1] HVAC systems design handbook/Roger W.Haines, C.Lewis Wilson.

[2] HVAC and the Building: Siamese Twins (An integrated design pproach) Hugo Hens - HVAC\&R Research - 1995

[3] A.K. Mishra, M.G.L.C. Loomans, J.L.M. Hensen, Thermal comfort of heterogeneous and dynamic indoor conditions - An overview, Building and Environment, Volume 109, 2016

[4] D\&R International Ltd, 2010 Building Energy Data Book.: U.S Departement of Energy DOE, 2011.

[5] Konstantinos D. Patlitzianas, Konstantinos Iatropoulos and John Psarras Haris Doukas, "Intelligent building energy management system using rule sets," Building and Environment, Oct 2006.

[6] Victor M. Zavala, "Real-Time Optimization Strategies for Building

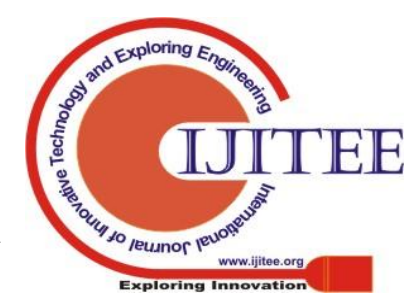


Systems,"2011,http://www.mcs.anl.gov/uploads/cels/papers/APT_70 592_Zavala_Paper_071411.pdf.

[7] J. Cockroft, S. Conner, J. W. Hand, N. J. Kelly, R. Moore, T. O'Brien, P. Strachan J. A. Clarke, "Simulation-Assisted Control in Building Energy Management Systems," Energy and Buildings, no. 34, pp. 933-940, 2002

[8] Haris Doukas, Konstantinos D. Patlitzianas, Konstantinos Iatropoulos, and John Psarras, "Intelligent building energy management system using rule sets," Building and Environment, vol. 42, pp. 3562-3569, October 2006

[9] Matthias Schuss, Robert Zach, Kristina Orehounig, and Ardeshir Mahdavi, "Emperical Evaluation of a Predictive Simulation- Based Control Method," in 12th Conference of International Building Performance Simulation Association, Sydney, 2011

[10] Lu Lu, Wenjian Cai, Yeng Chai Soh, and Lihua Xie, "Globa Optimization for overall HVAC System _ part I Problem Formulation and Analysis," EnergyConversion and Management, vol. 46, pp. 99-1014, August 2004.

[11] A. Pouliezos, G. Stavrakakis, C. Lazos D. Kolokosta, "Predictive Control Techniques for Energy and Indoor Environmental Quality Management in Buildings," ELSEVIER, no. 44, pp. 1850-1863, 2009

[12] John M. House, Curtis J. Klaassen, Morteza M. Ardehali and Theodore F. Smith Floyd E. Barwig, "The National Building Controls Information Program," vol. 3, pp. 1-14, 2002

[13] $M$ and Smith, T.F. Ardehali, "Literature Review to Identify Existing Case Studies of Controls-Related Energy- Efficiency in Buildings," Department of Mechanical Engineering, The University of Iowa, Iowa City, Technical Report ME-TFS-01-007 2001

[14] R.J. Meador, S. Katipamula and M.R.Brambley D.D. Hatley, "Energy Management and Control System: Desired Capabilities and Functionality," Pacific Northwest National Laboratory Richland, Washington, Technical Report PNNL-15074, 2005. [Online]. Energy Management and Control

[15] Hui Sam C.M. and Joseph C. Lam, 1991, Overall Thermal Transfer Value (OTTV)- a review, Hong Kong Engineering, September 1991

[16] ANSI/ASHRAE/IES Standard 90A-1980, Energy Conservation in New Building Design, American Society of Heating, Refrigerating and Air-Conditioning Engineers, Atlanta, 1980

[17] Hui, S. C. M., (1997), overall thermal transfer value (OTTV): how to improve its control in Hong Kong, In Proc. of the One-day Symposium on Building, Energy and Environment, 16 October 1997, Hong Kong, pp. 12-1 to $12-11$

[18] Saidur R., Hasanuzzaman M., Hasan M.M. And Masjuki H.H.,(2009) ‘ Overall Thermal Transfer Value of Residential Buildings in Malaysia, Journal of Applied Sciences 9(11), 2009, pp. 2130-2136

[19] Lam, J.C. and Hui, S.C.M., 1996, A review of building energy standards and implications for Hong Kong, Building Research and Information, 24(3), pp 131-140

[20] Variable Refrigerant Flow Systems By William Goetzler, Member ASHRAE, published in ASHRAE Journal, April 2007. ( Copyright 2007 American Society of Heating, Refrigerating and Air-Conditioning Engineers, Inc.

[21] https://www.elcot.in/it_parks_salem.php

\section{AUTHORS PROFILE}

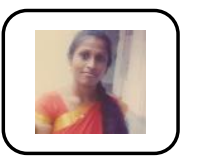

I have completed Under graduate B.Arch in 2008-2013 at Adhiyamann college

of engineering, Hosur. My title of the Thesis is Construction skills and promotion center, chengalpattu, Chennai. Completed M.Arch (Construction Project Management) in 2013-2015 at M.G.R University, Chennai. And I also completed a Postgraduate diploma in Urban Planning and Development (PGDUPL) 2018-2019 in Indira Gandhi national open university. I had a 5 years of teaching experience in various institutions. My teaching career starts in August 2013. 2013-2014 worked as an Assistant professor in Surya school of Architecture, Villupuram.2014-2016 worked as an Assistant professor in Dhanalakshmi school of Architecture, Perambalur. 2016-2017 worked as an Assistant professor in VPMM College of Architecture in Srivilliputhur. 2017 to Till date working as an Assistant professor in Kalasalingam school of Architecture, Krishnankoil. I have organizedvarious a guest lecture such as The Architects journey -Exploring your future in architecture at Madurai zonal level schools. I have delivered a guest lecture about Future career in Architecture at TMHNU Matriculation Hr Sec School, Muthuthevanpatti, Thenni. I also went as a External examiner in various institutions such as AMMAS,Chennai. \& MAM School of Architecture,Thiruchy. \& PRIME
NEST school of Architecture,Thiruchy. I am also a member of Council of Architecture, (COA) Delhi. 